\title{
[ Memory, Culture and Identity: A Cultural Reading of The Legends of Pensam ]
}

\section{Ujjwal Jana and Tanushree Dutta}

Pondicherry University, Puducherry, India

[Abstract] Located at the intersections of memory, culture and identity, this paper attempts a literary and cultural reading of Mamang Dai's novel The Legends of Pensam (2006), an extraordinary piece of tribal narrative from the North-Eastern part of India, imbued with the colours of its traditions and the flavours of its geography. This paper argues that literature, in particular tribal literature, has the potential to uncover the profound wealth and resources of an underrepresented culture and tradition camouflaged behind the curtains of mainstream cultures. This paper focuses on the robustness of literature in preserving a marginalized culture informed by the multiplicity of its rich cultural traditions, social beliefs, religious views, oral tradition, and colourful lifestyle. The study focuses on how a literary work can preserve and document the history, culture and identity of the Adi tribes, imbued with lore and myths from the memory of people defining their unique identities.

[Keywords] culture; oral; tradition; identity; North-East India; myths; memory 


\section{[1] Introduction}

Located at the intersections of memory, culture and identity, this paper attempts a literary and cultural reading of Mamang Dai's novel The Legends of Pensam (2006), an extraordinary piece of tribal narrative from the North-Eastern part of India, imbued with the colours of its traditions and the flavours of its geography. It seeks to unravel the unexplored layers of tribal cultures and traditions camouflaged by the predominance of so-called mainstream cultures. The paper examines the way in which Mamang Dai's novel represents the oral tribal culture of North-East India, which offers an alternative to the Western cultural and economic model rooted in the idea of progress. The study seeks to explore the rich threads linking the tribal lore with the people's past as well as with their land, and to investigate how it is facilitated by the use of memory. It will be argued throughout the paper that an ethnographic approach enables us to trace the lines of memory, culture and identity in Mamang Dai's landmark novel The Legends of Pensam.

This paper is structured into four sections: The first presents a critical analysis of the primary text, and the second explores the role of memory which helps the oral tradition continue over multiple generations. The third section explores the unique and ethnic cultural roots of the Adi tribes, and the fourth section addresses the question of the identity of tribal communities in the eyes of mainstream cultures.

\section{[2] Critical Analysis and Plot Overview}

Dai's The Legends of Pensam is regarded as a powerful repository of knowledge. It depicts the beautiful and magnificent landscape girdled with lush green woodlands, the flow of silver streams, the sounds of ethnic festivals, and the conglomeration of multiethnic societies. In The Legends of Pensam, Dai transports the readers to a fascinating corner of the world, a place which is inhabited by the Adi tribes: the Himalayan hills of Arunachal Pradesh, India. The Adi tribes practice an animistic faith that is woven around forest ecology, in consonance with the natural world and with their unique sense of history. It is a place where indigenous peoples say: "When you look at the land you forget your aches and pain" (Dai XI). According to the Adi tribes, the human world and the natural world are not two different entities; rather they are complementary to each other. The work gives us a glimpse into the minds of tribal people who reject the anthropocentric view of the universe. Mamang Dai weaves a thread of cultural harmony and integrity by portraying the Adi tribes' culture and way of life. The Legends of Pensam is an entangled web of anecdotes, history, culture and images - all harmonized within the home territory of the Adi tribes, inhabiting the heart of the Siang Valley. In the epigraph to the novel, Dai states:

In our language, the language of the Adis, the word 'pensam' means 'in-between'. It suggests the middle, or middle ground, but it may also be interpreted as the hidden spaces of the heart where a secret garden grows. It is the small world where anything can happen and everything can be lived; where the narrow boat that we call life sails 
along somehow in calm or stormy weather; where the life of man can be measured in the span of a song. (Unpaged)

Dai toys with the idea of the Adi community being tangled in between the loop of reality and myth. She beautifully knits four interconnected elements of tribal lore - a "diary of the world", a "song of the rhapsodist", "daughters of the village" and "a matter of time" which set readers' hearts palpitating. There are memorable characters in the novel whose time-honoured belief systems and customary rituals revolve around their vulnerable lives. The prologue of the novel begins with a myth about a lady who battled against a supreme power to weave a tapestry.

The first section seems illusory, fanciful, unfettered and open-ended with regard to the narratives rendered in the novel. The character Hoxo mysteriously falls from the sky, and at the moment when he opens his eyes, he sees green walls of trees, bamboo and a green waterfall that sprays his cheeks. He is found by a villager named Lutor, who is the famous chief of the Ida clan. None of the villagers ask questions about the child, as their minds are filled with superstitious beliefs. Later, Lutor is killed in a hunting incident after he unfortunately sees Birbirik, a water serpent whose horned head resembles a malignant spirit; this causes Lutor's death.

Other strings of stories soon unfold; here we find stories within stories connected to Adi tribal myths, supernatural powers, spirits, culture, etc. This part of the novel tells of the mysterious deaths of the characters inside the thick and dense woodlands of the hills. The stories are arduous to interpret with conventional logic, but the Adi tribes had unwavering beliefs in the tales. As Pinyar the widow says, "Faith is everything" (Dai 35). Pinyar was fatigued with her life, having been betrayed by her husband, lost her son, and had her home burned down. As we can read, "It seems my destiny is cursed" (Dai 28). The last story in this section reflects the harsh reality of the foreigners' arrival in the Adi tribes' untouched lands, representing an affliction in the minds of the villagers. This sudden change ached the hearts of their community, as the deteriorating beauty of nature was something unbelievable to their tender eyes. As Hoxo says, "We saw a new glimmer in the distance. Our footsteps led us down unknown paths" (Dai 42). Yet these changes in the society brought a new spark in their hearts, a desire to preserve their roots and to lead a traditional tribal lifestyle.

The second section of the novel begins with the arrival of migluns (Britishers) in the Adi lands; the new arrivals began to control the area by constructing roads, taking administrative power and spreading Christianity, marking the beginning of 'civilization' in a previously 'uncivilized' territory. The couple Mona and Jules visit the village from distant lands to learn about the culture and tradition of the tribal folk. Both of them participate in the village's traditional feasts and ceremonies, and they listen enthusiastically to the folk songs sung by the local villagers. They leave the village with bountiful memories, stories and experiences that they have gained from the Adi community, making their journey worthwhile.

The third section of the novel portrays the love story of Nenem, a legendary woman who falls in love with a British officer named David; their love blossoms for a while before 
they are separated. David is posted to a different place, and Nenem, a lover of nature, is unable to sever her indigenous roots and travel to a foreign land for the sake of love. This shows how the tribal people have interlinked their lives with Mother Nature for survival. Nenem says: "No one dies of love. I loved him, and now I am enough on my own" (Dai 109). She is a symbol of a legend, with the heart of an angel and the mind of a dove. Later, she weds Kao and is blessed with a daughter, Losi. Uncertainty strikes her life like thunder as she has to abandon her village and move to another place when her village is flooded following an earthquake. She loses her happiness, pain whirls within her fragile heart, and she ultimately leaves this world. Nenem's life reveals how removal from a person's roots causes premature death and how one's life is linked with the wonders of nature.

The fourth section of the novel throws light on the ongoing changes in the community, which cause a sense of terror among the masses. Innocence is lost, beauty is diminishing, and the aura is foul-smelling as the trumpets of modernity blow. The resentment towards the changing times is highlighted through the characters. As Larik says, "This terrible road is all they have for us in $\mathbf{5 0}$ years! And what does it bring us? Outsiders. Thieves. Diseases" (Dai 156). In spite of the changes, the villagers adhere to their customary rituals, culture and beliefs, authenticating their love for the pristine land. The novel portrays the rich oral tradition, unique indigenous culture and community life of the Adi tribes. In the text, members of the old generation whistle to protest against the change and to preserve their indigenous roots from destruction. The villagers thus oscillate in a space between traditional and modern ways of life. Dai displays the colours of the Adi tribes' vibrant culture and history throughout the narrative, creating an aura of amazement at their endeavours to safeguard their pure culture by recording oral folklore in printed form for future generations.

\section{[3] Memory as a Catalyst}

This part of the paper highlights memory as a tool for oral literature, which excavates tribal culture in the form of folklore. Folklore is an elixir of the cultural memory and cultural knowledge of a particular community or group of people. The oral tradition is quite fascinating, as unlike written literature, oral literature is predominantly dependent on the power of memory for its survival in a given space and time. Memory is engaged in preserving the traditional knowledge, beliefs and identities of a particular community, retaining the community's wisdom for future generations. According to Nietzsche:

While in the world of animals genetic program guarantee the survival of species, human must find a means by which to this problem is offered by cultural memory, a collective concept for all knowledge in the interactive framework of a society and one that obtains through generations in repeated societal practice and initiation. (Assmann and Czaplicka 126)

Assmann says that "Cultural memory is a form of collective memory, in the sense that it is shared by a number of people and that it conveys to these people a collective, that 
is cultural, identity" (110). Cultural memory, therefore, ties a knot between 'memory' on one hand and the socio-cultural milieu on the other. It brings out the fact that memory is not entirely individual, but rather shaped by collective experiences that are undergone within a community. Memory plays a vital role in preserving the past in the form of narratives, as in folklore, which ultimately serves to manifest a community's self-image. Cultural memory has preserved many rituals, beliefs, ideas and customs of forgotten times, and it has safeguarded mysterious things which the future generation's tellers of tales might not have articulated. In oral literature, traditional stories link indigenous peoples with their pristine land; this strengthens cultural roots, which is central to the people's identity. "Cultural memory is based on fateful events of the past; on fixed points which he calls 'figures of memory”" (Assmann and Czaplicka 129). Hence, memory develops our awareness of individuality at both the personal level and the collective level.

Dai's novel The Legends of Pensam can be critically examined in the light of cultural memory and how it transmits the words of wisdom and bodies of knowledge of past events orally, in the form of folklore: stories, traditional dances, songs, rituals and superstitious beliefs. The literature of the hill tribes constitutes the realm of memory, which has been accumulated in the form of oral literature, and is thus able to offer insights into the tribes' cultural and traditional life.

In The Legends of Pensam, Dai beautifully interweaves tribal lore with thoughts and emotions peculiar to the Adi tribes' pristine land and culture; the characters in the novel recollect their past in tales of creation, myths, customs, spirits, etc. in the realm of cultural memory. Oral literature is all about the serial recall of events in one's mind - and it thus revolves around a community's social and mental life. Dai adopts a creative framework of narratives in the form of storytelling; we thus encounter stories within stories, drawn from the myths and legends of the Adi community. At the beginning of the novel, Lutor narrates a myth in which Biribik, the water serpent, seems malevolent in the eyes of the villagers. Lutor recalls a past incident and tells Lutor's son, Hoxo: "Everyone present knew the story of Biribik, the water serpent. No one, for generations now, remembered the name of the first person who had seen it, but the event was fixed in their collective memory" (Dai 9).

The transmission of myth is highly reflective of the capacity of the memory which was fixed in the minds of Adi tribespeople. Lutor, the teller of the myth, creates a link to the next generation of people and their tribal society; the chain of preserving the myths and legends of the past will thus continue in the future through the act of 'remembering' and 'recalling'. Cultural memory thus preserves the past in symbolic forms, as delineated in oral myths. Dai also gives us the insight that the Adi people's minds were sharp and wise, no matter how old they physically appeared: "She was very old now but her mind was sharp and alert. She was quiet when I told her about Mona's interest in the stories of the village" (Dai 13). Dai presents the tribal people's strong mental capacity, which helps to construct and preserve their ethnic identity. Memory enables them to use remembrance as an efficient tool for ensuring the continuity of the community's cultural, ethnic and social behaviour. The outsiders Mona and Jules visited the village and found the 
atmosphere exhilarating, with the Adi tribes' ethnicity and culture vibrantly showcased in cultural performances. The audience witnesses how Adi society's collective memory is enacted in this way: "They had lit a big fire in anticipation of our stay and for the long night of stories, when myth and memory would be reborn in the song of ponung dancers" (Dai 49). The story of the supernatural beings known as 'miti-mili' reflects the Adi tribes' mystical beliefs. For Pinyar, the widow, the death of hunters in accidents is no surprise to her, as it is the irresponsible behaviour of people which causes such deaths. She narrates a story involving the preparation of rice beer with a special yeast:

Once upon a time, there lived a race of supernatural beings called the miti-mili. These small, quiet people were the first to make the mysterious si-ye that is the yeast used to ferment rice into beer. Before the miti-mili race disappeared, deranged by strange visions, they gave this sacred powder to mankind, and a strong belief grew that si-ye had special powers and that it was something to be handled with respect. (Dai 28)

Pinyar believes the myth is authentic, and when her husband is killed by a man in a hunting accident, she holds no resentment against the culprit, as she attributes his act to the spirit of si-ye, stating: "There is a bad spirit lurking in the spirit that makes men go mad..." (Dai 29). Pinyar's superstitious beliefs about the miti-mili race are highlighted, as her memory causes her to believe the mythical stories. She also shares the story with other visitors, seeking to make them believe. Hence, memory plays a crucial role not only in passing on such myths from generation to generation, but also in the geographical knowledge of the community's land, which creates their unique identity. Memory and identity are entangled on an individual level, as John Locke states: "there is no such thing as an essential identity, but [...] identities have to be constructed and reconstructed by acts of memory, by remembering who one was and by setting this Past Self in relation to the Present Self" (qtd. in Assman 6).

Dai stresses the role of memory for the Adi tribes: it is a treasure-house for their fractured identity and a resource for its revival, as it is not only an individual's memory, but also the very memory of their land, of their culture, of their beliefs, of their ancestors; it is a unique quality that is inherent in their resilient minds.

\section{[4] Culture as a Metaphor}

According to the Oxford Dictionary Online, the word 'culture' comes from a Latin root referring to civilization, but societies gradually began to apply the term to the act of cultivating human minds and manners. Culture means the shared values, norms, beliefs and identity of a specific community. The Adi tribes' ethnic traditions, myths, religious rituals and so on are handed down from generation to generation through a constant process of performances and reiterations of traditional norms. Shared experiences, shared memories, shared beliefs are what constitutes a community's culture. Tribal cultures are rooted in a specific landscape and history, as they have a deep connection with their pristine land. Culture constitutes the practices, representations, languages and customs of any 
society. In the novel, Dai presents a society whose local myths, traditions and cultures represent a unique lifestyle, which can be assumed to be a cumulative force helping to preserve their cultural legacy.

In The Legends of Pensam, Dai sketches the aura of the traditional environment of the Adi community residing in Arunachal Pradesh and describes their arduous attempts to safeguard their cultural identity. In the author's note on the novel, it is stated that the Adis practiced an animalistic faith woven around forest ecology and the natural world. This faith manifests the connections between the lives of tribal people and Mother Nature. At the beginning of the novel, Hoxo, the boy who mysteriously falls from the sky, has unique prophetic powers as he ponders over the mysteries of the society. Hoxo himself is mythicized; he possesses no parental lineage, no origin, no history. This is typical of tribal myth creation. Hoxo is one of the narrators who knits the intricate webs of stories that make up the novel. The stories progress by manifesting numerous myths, such as that of Birbik, the water serpent, whose appearance causes humans to die unnatural deaths. There is a myth of the superhuman beings known as miti-mili; Kamur, the son of Pinyar, who murdered his own daughter, was believed by the society to have had his soul possessed by a malevolent spirit because his parents and grandparents had failed to follow customary rites and rituals in the past. There is the myth of the travelling vessel 'Danki' from the Lotang family of the Migu clan, which was believed to bring fortune to the family - and so on. Biju's essay "Myths and Legends from Netherworld in Mamang Dai's novel The Legends of Pensam" states that myths and legends play a crucial role in a world advancing towards a post-human identity:

It is often highlighted that ours is a posthuman world where human capacities and capabilities are enhanced with the technological innovations. In other words we have to define human beings as technical beings. [...] In this regressive adventure, myths and legends become the threshold of wonderful wisdom and knowledge that lead humanity forward and through which the ordinary and banal activities become quite meaningful. (Biju 216)

Myths and stories shape a culture rooted in belief systems which, through epochs of time, are manifested as sets of rituals, rites or taboos in a particular society. They exhibit beliefs, practices and symbolic representations that mould a community's perception of the past and its future development. The novel reveals the villagers' belief systems, which are closely related to certain dances, songs or myths; the narrator and their friends attend cultural performances in which ponung dancers respond to the narratives told by Miri, the rhapsodist. In the section 'Songs of Rhapsodists', before the end of the cultural performances by the ponung dancers, Miri sings songs to preserve the stories about beginning of the world, the sword of five metals that ignited the bonfire of the village, and the shaman says: "These are the stories, rhapsodies of time and destiny, that he must guard" (Dai 55).

The Adi community's performances in religious rites, the creation of strange myths and the powerful oral narratives in the novel represent the cultural legacy of this 
community. Although the changing times are creating threats to the Adis' cultural systems, the tribal people are nevertheless holding on to their cultural norms and rituals, authenticating their values of love, dignity and integrity. North-Eastern Indian cultures are rich, unique and outstanding in their own right, being quite different from the mainstream cultures of India.

\section{[5] Questions of Identity}

This section focuses on questions related to the identity of the Adi tribes in Arunachal Pradesh. The term 'identity' is often used to refer to feelings of community in relation to a group's social structure, religion, nationality, etc. Widely held notions of tribals as 'half-naked' are still prevalent; tribals are seen as differing from the mainstream cultures of India. Claude Levi-Strauss, in his book The Savage Mind, dismantles the polarity between a rationalized mind and a savage mind in his opening chapter "Science of the Concrete" (qtd. Swami, 2). Jasbir Jain states:

The intuitive minds desire for exactitude knowledge and objective knowledge is as real as the scientific mind's. Knowledge which grows out of need and is the basis of survival, often in hostile environments, emerges through similar processes of observation, even if they are not connected to scientific concepts. (Swami 2)

In this world, full of division and segregation based on religion, culture, race and ethnicity, marked by the concept of 'Othering' as developed by Spivak, one culture is regarded as 'savage' and the other as 'civilized'. This binary opposition calls forth the question of identity in the minds of 'the Other'. In The Legends of Pensam, Dai presents a society which is clinging to a position between traditional and modern life; the arrival of the British in the Adis' pristine land (to 'civilize' the 'uncivilized') ushered in societal changes which brought the tribespeople's cultural and ethnic identity into question. The narrator states: "The early decades of the $20^{\text {th }}$ century were times of great upheaval, when even remote hills were opened up to the world" (Dai 47). There was a dire need to preserve the community's identity by speaking out against the dominating alien forces, the ones trying to conquer their pristine land and cultural identity. Dai thus presents history, oral narratives, agricultural practices, rituals, traditional dances and songs in the novel. She counter-attacks the notion of 'Othering' by displaying the Adi tribes' rich culture and the villagers' zeal for protecting their identity from being questioned or assumed to be inferior. The wholeness with the real world, the natural world and the history of the people is what constitutes the tribes' sensitivity. The beauty of oral literature, the relation with mother nature, the creation stories, the myths and legends - these are the tools which define the cultural identity of the Adi tribes, an identity which is worth no less than that of Western culture. Identity binds a community and brings a sense of oneness among the masses by constructing a collective voice and experiences whirling within their hearts. For many years, the tribals have stood tall to protect their cultural identity from 'Othering'. Mahasweta Devi acknowledges that one learns from marginal communities by 
recognizing their inherent patience, their ability to endure, their oneness with the environment, their histories of courage and resistance (Swami 4). Mamang Dai writes down the tribespeople's histories and tales to resurrect their identity as one that is unique and distinct from the rest of the world. The transfer of oral narratives into printed form is an attempt to preserve the community's cultural identity, as the written form is far longer-lasting than oral narratives. In an interview, Mamang Dai has said: "Ours is an oral tradition you know, I was trying to meet people and collect and record these oral narratives. You know, the small histories which were getting lost and when you talk to people even small things can trigger these memories off."

There are discussions to be had as to how identities are manifested in history, cultural beliefs, memories, places and spaces as much as in the political state of affairs. Dai has exhibited her tribal community's identity, bringing a healing effect to its long-fractured identity.

\section{[6] Conclusion}

This paper has explained that memory, culture and identity are interlinked concepts in Mamang Dai's work The Legends of Pensam. It is interesting to observe how ethnography as a research tool helps us to explore the subjective meanings of culture, ways of cultural life, questions of identity, and the role of memory in a tribal community of Arunachal Pradesh, North-East India. The paper has investigated the cultural roots of the Adi tribes in an attempt to understand and acknowledge their unique way of life and its links from past to present times. This study has highlighted a paradigm shift in the minds of readers who may previously have considered tribals to be 'savages', underestimating their rich talents and knowledge of the ethnic culture that is in their blood. It has been an attempt to show how literature can reconfigure the standards of a marginalized community as against the mainstream communities. The cultures of North-East India are experiencing tremendous changes; an alarm has been sounded highlighting the necessity to safeguard their ethnic culture by documenting and preserving it for posterity.

\section{[Bibliography]}

Assmann, Jan, and John Czaplicka. “Collective Memory and Cultural Identity.” New German Critique 65 (Spring - Summer, 1995): 125-133.

Assmann, Jan. “Communicative and Cultural Memory”. Cultural Memory Studies: An International and Interdisciplinary Handbook. Eds. Astrid Erll, and Ansgar Nünning. Berlin: Walter de Gruyter, 2008. 109-118.

Biju, M.A. Myths and Legends from Netherworld in Mamang Dai's Novel, The Legends of Pensam. Retrieved from strandrewscollege.ac,in/wp-content/uploads/2018/06/Myths-and-Legends-fromNetherworld-in-Mamang-Dai's-Novel-The-Legends-of-Pensam. pdf, 2018.

Dai, Mamang. The Legends of Pensam. Oxford: Penguin Books, Kindle ed., 2006. 
Erll, Astrid, Ansgar Nünning, and Sara B. Young. Cultural Memory Studies: An International and Interdisciplinary Handbook. Berlin: Walter de Gruyter, 2008.

Oxford English Dictionary Online. Oxford, England: Oxford University Press, 2002. Internet resource.

Swami, Indu. Exploring North-East Indian Writings in English. New Delhi: Sarup Book Publishers, 2012. Print.

\section{[Address]}

Pondicherry University

Dept. of English

School of Humanities,

RV Nagar, Kalapet

Pondicherry-605014, India

ujjwal.dakshini@gmail.com

UjjwaI Jana teaches English at the Department of English, Pondicherry University, India. His areas of interest include Indian Aesthetics, Translation Studies, Cultural Studies, and Digital Humanities. He was a Fulbright visiting lecturer in the India studies program at Indiana University, Bloomington, USA in 2007-2008. He was a visiting postdoctoral faculty member at the Department of English, Leipzig University in 2014. He was a visiting postdoctoral faculty member in the Department of English, Johannesburg, South Africa in 2017. He has been awarded the MHRD Government of India Funded International Collaborative Project in Digital Humanities in the Indian Rim under SPARC (the Scheme for Promotion of Academic and Research Collaboration) to collaborate with Western Sydney University, Australia for 2019-2021.

Tanushree Dutta is pursuing her Master's degree in English Literature in the Department of English, Pondicherry University, India. Her areas of interest include Literary Studies and Translation Studies. 